\title{
Influence of tris(2,3-dibromopropyl) isocyanurate on the expression of photosynthesis genes of Nannochloropsis sp.
}

\author{
Ling Wang ${ }^{\mathrm{a}}$, Chun Wang ${ }^{\mathrm{a}}$, Minggang Zheng ${ }^{\mathrm{b}, *}$, Yinghua Lou ${ }^{\mathrm{a}}$, Maoyong Song ${ }^{\mathrm{c}}$, Zijian Wang ${ }^{\mathrm{a}}$, Li Zheng ${ }^{\mathrm{b}}$ \\ a College of Chemistry and Chemical Engineering and Environment, Qingdao University, Qingdao 266071, PR China \\ ${ }^{\mathrm{b}}$ Research Center for Marine Ecology, The First Institute of Oceanography, State Oceanic Administration of China, No. 6 Xianxia Ling Road, Hightech Park, Qingdao 266061, PR China \\ c State Key Laboratory of Environmental Chemistry and Ecotoxicology, Research Center for Eco-Environmental Sciences, Chinese Academy Science, Beijing 100085, PR China
}

\section{A R T I C L E I N F O}

\section{Article history:}

Accepted 17 February 2014

Available online 25 February 2014

\section{Keywords:}

Tris(2,3-dibromopropyl) isocyanurate

Nannochloropsis sp.

Photosynthesis

psaA

$p s b C$

\begin{abstract}
A B S T R A C T
The proteins encoded by $p s a A$ and $p s a B$ form a heterodimer, an essential compound of photosystem; while the protein encoded by $p s b C$ binds with chlorophyll $a$ in photosystem II, serving as antennae in photosystem. Here we report that a heterocyclic brominated flame retardant, tris(2,3-dibromopropyl) isocyanurate (TBC), inhibited the expression of $p s a A$ and $p s b C$, then leads to the decrease of Nannochloropsis sp.'s growth biomass. TBC exposure inhibited the expression of $p s a A$ and $p s b C$ at $10,100 \mathrm{ng} / \mathrm{mL}$ slightly and $1000 \mathrm{ng} / \mathrm{mL}$ significantly. In addition, TBC was found to slow down the growth of Nannochloropsis sp. at concentrations ranging from 10 to $1000 \mathrm{ng} / \mathrm{mL}$. These results indicated that TBC influenced both photosynthesis and growth performance of Nannochloropsis sp.
\end{abstract}

(c) 2014 Elsevier B.V. All rights reserved.

\section{Introduction}

Tris(2,3-dibromopropyl) isocyanurate (TBC) has a wide range of applications, for example, in polyolefin, polyphenyl alkene, unsaturated polyester and synthetic rubber and fibers (Xiong, 1999). In China, TBC has been widely utilized in polymer products since 1980s. Its annual production of TBC in China was $>500$ metric tons in 1990s (Cao, 1996; Lv et al., 1999). TBC is a heterocyclic hexabrominate with high octanol water partition $\left(\mathrm{K}_{\mathrm{ow}}\right)$ and octanol air partition $\left(\mathrm{K}_{\mathrm{oa}}\right)$ coefficient. The high $\mathrm{K}_{\mathrm{ow}}\left(\log \mathrm{K}_{\mathrm{ow}}=7.37\right)$ indicates that TBC is easily accumulative in both sediment and organism's body. The exact statistics of the world production of TBC is not available at present; however, its residue in environment must be vigilantly attended. Actually, TBC is a BFR (brominated flame retardant) with a high thermostability, a low viscosity and a tendency to discoloration and corrosiveness. It has been found in many environments (Johnson et al., 2013; Ruan et al., 2009), and its residue is continuously increasing recently (Cristale et al., 2013; Wang et al., 2013).

TBC exposure disrupts the development and endocrine of zebrafish embryo, damages their mitochondria and interferes in their gas bladder

Abbreviations: psaA, photosystem I P700 chlorophyll $a$ apoprotein A1; psaB, photosystem I P700 chlorophyll $a$ apoprotein A2; psbC, photosystem II CP43 chlorophyll apoprotein; bp, base pair(s); $\mathrm{EC}_{50}, 50 \%$ effective concentration; cDNA, DNA complementary to RNA.

* Corresponding author.

E-mail address: zmg@fio.org.cn (M. Zheng). inflation (Li et al., 2011; Zhang et al., 2011). It has been speculated to be toxic to neuronal cells (Qu et al., 2011). Algae are widely distributed in lakes and seas, which are sensitive to contaminants. Algae have been chosen as the most important indicators in aquatic environmental assessment (Chen et al., 2011; Sidharthan et al., 2002; Wu et al., 2009). As an intensively studied microalga, Nannochloropsis sp. is abundant in aquatic environment and easy to culture. In order to investigate the relationship of TBC concentration with growth and photosynthesis of Nannochloropsis sp., this work had studied the influence of TBC exposure concentration to two important photogenes of Nannochloropsis sp.

The proteins encoded by psaA and psaB form a heterodimer, an essential compound of photosystem I (Hall and Rao, 1999); while the protein encoded by $p s b C$ binds with chlorophyll $a$ in photosystem II, serving as antennae in photosystem II (Bricker, 1990). In this study, the expression of two Nannochloropsis sp. photosynthesis essential genes, $p s a A$ and $p s b C$, were analyzed in order to assess the damaging risk of waterborne $\mathrm{TBC}$ to aquatic life.

\section{Materials and methods}

\subsection{Chemicals and regents}

Tris(2,3-dibromopropyl) isocyanurate (TBC, purity 97\%) was purchased from Sigma-Aldrich (USA). Dimethylsulphoxide (DMSO) was purchased from Merck KGaA (Germany). Stock TBC (100 $\mu \mathrm{g} / \mathrm{mL}$ ) was prepared by dissolving TBC monomer in DMSO; while working TBC was diluted from the stock solution with DMSO. No observed effect 
concentration (NOEC) of DMSO was determined ahead of TBC treatment (Aldenberg and Slob, 1993). In order to study the effect of TBC to Nannochloropsis sp. more accurately, the NOEC of DMSO had been added each experiment. Working TBC concentrations were fixed based on the preliminary test using the TBC with the ranges from 5 to $5000 \mathrm{ng} / \mathrm{mL}$. In the present work, the selected TBC concentrations included 10,100 and $1000 \mathrm{ng} / \mathrm{mL}$.

\subsection{TBC treatment}

Nannochloropsis sp. was obtained from The First Institute of Oceanography of State Oceanic Administration of China. The $8000 \mathrm{~mL}$ alga that used in experiment was cultured in two containers (Erlenmeyer flasks, $5000 \mathrm{~mL}$ in volume) with $4000 \mathrm{~mL} \mathrm{f} / 2$ medium (Guillard and Ryther, 1962), respectively, under cool-white fluorescent lamps (4000 lx) following a rhythm of $14 \mathrm{~h}$ light and $10 \mathrm{~h}$ dark and at $24 \pm$ $1{ }^{\circ} \mathrm{C}$ in order to obtain the algal biomass for TBC exposure. The medium was prepared with seawater, which was filtrated through a membrane of $0.45 \mu \mathrm{m}$ pore size and autoclaved at $121{ }^{\circ} \mathrm{C}$ for $20 \mathrm{~min}$ ahead of use. The alga at the middle of exponential growth phase was equally divided into 8 Erlenmeyer flasks ( $2000 \mathrm{~mL}$ in volume) and mixed with DMSO (final concentration $0.63 \%$, the NOEC). One flask was used as the control; while the remaining 3 were mixed with 10,100 and $1000 \mathrm{ng} / \mathrm{mL}$ $\mathrm{TBC}$, respectively. Two parallel samples for every flask were set in this experiment. The alga in all the 8 flasks ( $2000 \mathrm{~mL}$ in volume) was cultured under the condition set for obtaining the algal biomass for TBC exposure. The number of Nannochloropsis sp. cells was counted every another day. About $60 \mathrm{~mL}$ of algal culture was sampled at $0,12,24,48$ and $72 \mathrm{~h}$, respectively, with cells precipitated by centrifuging at $4{ }^{\circ} \mathrm{C}$ and $5000 \mathrm{rpm}$ for $15 \mathrm{~min}$ and stored at $-80{ }^{\circ} \mathrm{C}$.

\subsection{Expression analysis}

Total RNA was extracted with Trizol reagent (Beijing CoWin Bioscience Co., Ltd., China) according to the manufacturer's instructions, and stored at $-80{ }^{\circ} \mathrm{C}$. The first-strand cDNA was synthesized with RT-PCR kit (Transgen, Beijing, China) on a TP 600 Thermal Cycler Dice PCR (Takara Bio. Inc., Japan) following the manufacturer's instructions and stored at $-20{ }^{\circ} \mathrm{C}$. Primers were designed with Primer Premier 5.0 (http://blast.ncbi.nlm.nih.gov/Blast.cgi) and synthesized by Shanghai Sunny Biotechnology Co., Ltd. Primers (Table 1) were used to quantify the transcript of $p s a A$ and $p s b C$. In order to qualify the primers, the core region of $p s a A$ and $p s b C$ was amplified by predenaturing at $94{ }^{\circ} \mathrm{C}$ for $5 \mathrm{~min}$, followed by 30 cycles of denaturing at $94{ }^{\circ} \mathrm{C}$ for $45 \mathrm{~s}$, annealing at $55{ }^{\circ} \mathrm{C}$ for $45 \mathrm{~s}$, and extending at $72{ }^{\circ} \mathrm{C}$ for $45 \mathrm{~s}$, and an extra extension at $72{ }^{\circ} \mathrm{C}$ for $5 \mathrm{~min}$. The abundance of psaA (108 bp) and psbC (187 bp) transcript was determined with real-time quantitative PCR (RT-PCR) and TransStart ${ }^{\mathrm{TM}}$ Top Green qPCR SuperMix Kit (Transgen, China). The abundance of $\beta$-actin gene transcript was used as the internal control.

\subsection{Statistical analysis}

The abundance of gene transcripts and the number of cells were expressed as mean $\pm S D(n=3)$. Analysis of variance (ANOVA) and

Table 1

Primers used in this study.

\begin{tabular}{lll}
\hline Primer & Sequences $\left(5^{\prime} \rightarrow 3^{\prime}\right)$ & $\operatorname{Tm}\left({ }^{\circ} \mathrm{C}\right)$ \\
\hline F1 & TCCAACTATGGCGTGCTGAA & 59.90 \\
R1 & AATGAAACCAACCTGCGAACA & 60.50 \\
F2 & CCATTCTTGGTTATGACTGGCGT & 64.40 \\
R2 & CGGCTGCATTAACCGTAGGACTT & 67.70 \\
$\beta$-Actin F & ACGGCGTCTCACACACTG & 65.66 \\
$\beta$-Actin $\mathrm{R}$ & GCTTGACCATCCAATCGG & 63.80 \\
\hline
\end{tabular}

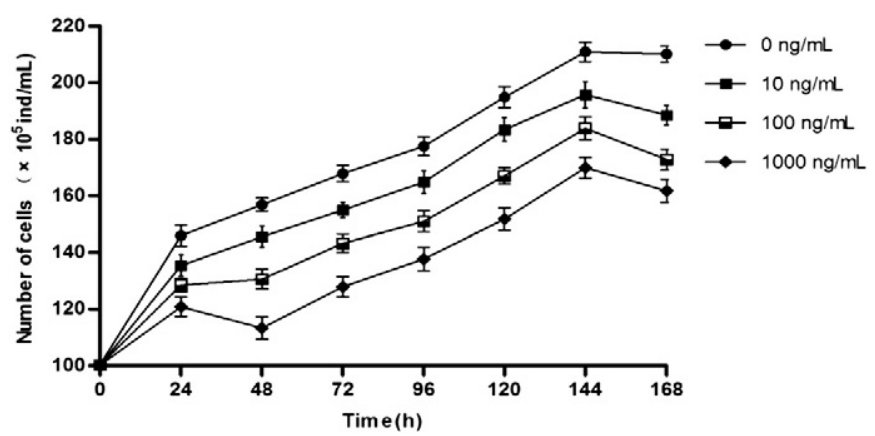

Fig. 1. The influence of TBC on the growth of Nannochloropsis sp.

Student's t test were conducted with GraphPad software5.0 (GraphPad Prism).

\section{Results and discussion}

\subsection{Growth performance of Nannochloropsis $s p$.}

The growth rate of Nannochloropsis sp. was significantly inhibited by TBC (Fig. 1) at concentrations ranging from 10 to $1000 \mathrm{ng} / \mathrm{mL}$ in a concentration dependent manner, the influence became significant with the concentration of TBC increasing. The $\mathrm{EC}_{50}$ of TBC has been determined (data not shown); however, such a concentration protruded what we may meet in environment. Therefore, the influence of TBC on the growth of Nannochloropsis sp. was determined in a concentration range as were selected. Compared with the control $(0 \mathrm{ng} / \mathrm{mL})$, TBC treatment $(10,100$ and $1000 \mathrm{ng} / \mathrm{mL})$ inhibited the growth of Nannochloropsis sp. obviously.

\subsection{Expression analysis of psaA}

The results were presented in Fig. 2. The expression level of $p s a A$ in control $(0 \mathrm{ng} / \mathrm{mL})$ increased during 0 to $48 \mathrm{~h}$, but slightly decreased at $72 \mathrm{~h}$. Contrarily, that of $p s a A$ decreased significantly when the alga was treated with TBC $(10,100$ and $1000 \mathrm{ng} / \mathrm{mL})(\mathrm{P}<0.05)$ from 12 to $72 \mathrm{~h}$, reaching the minimum at $48 \mathrm{~h}$. The reduction of the expression in TBC treated groups reached $71 \%(10 \mathrm{ng} / \mathrm{mL}), 91 \%(100 \mathrm{ng} / \mathrm{mL})$ and $94 \%(1000 \mathrm{ng} / \mathrm{mL})$, respectively. TBC downregulated the transcription of psaA gene, the higher the concentration the more obvious the regulation. Although the expression level of psaA increased slightly at $72 \mathrm{~h}$, it was still lower $50.5 \%(10 \mathrm{ng} / \mathrm{mL}), 68.8 \%(100 \mathrm{ng} / \mathrm{mL})$, and $82.8 \%$ $(1000 \mathrm{ng} / \mathrm{mL})$, respectively, than that of control.

The first response of plants to stresses is to protect the cells from possible abiotic damage by weakening the photosynthesis (Bilgin et al., 2010). The photosynthetic activity of plants was reported to be significantly reduced under diverse stresses including temperature, light, heavy metals, toxic substances and among others (Dawson and Dennison, 1996; Han et al., 2003; Li et al., 2005). Besides, some

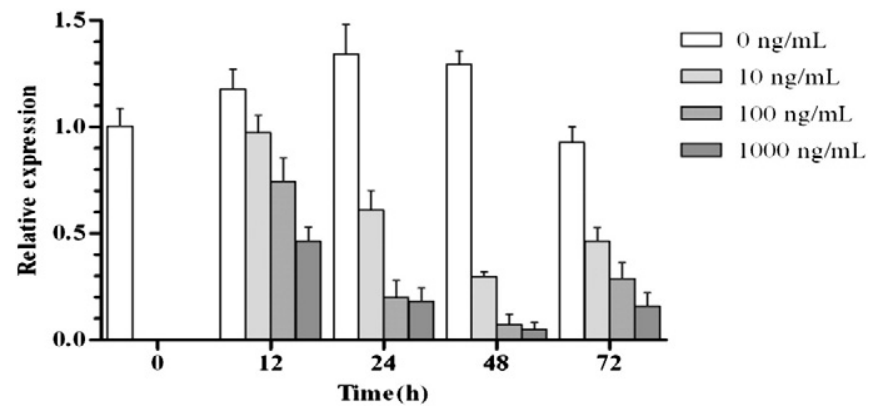

Fig. 2. The abundance of $p s a A$ gene transcript in Nannochloropsis sp. treated with different concentrations of TBC. The abundance was mean \pm SD $(n=3)$. 


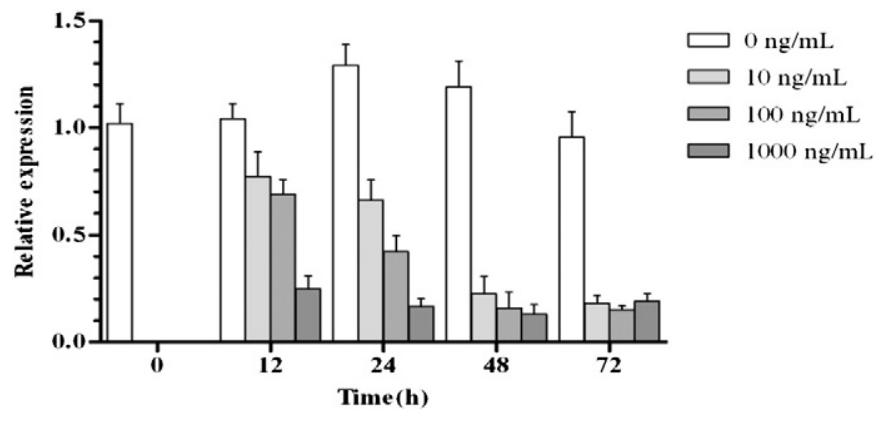

Fig. 3. The abundance of $p s b C$ gene transcript in Nannochloropsis sp. treated with different concentrations of TBC. The abundance was mean $\pm \operatorname{SD}(n=3)$.

mutations caused by diverse mutagens including TBC may also reduce the photosynthetic activity (Rochaix, 1996). PsaA is one of the key gene encoding proteins in reaction center PS I. Therefore, it is understandable that the expression level of psaA was inhibited when Nannochloropsis sp. was exposed to TBC.

\subsection{Expression analysis of $p s b C$}

From 0 to $24 \mathrm{~h}$, the abundance of $p s b C$ gene transcript of the control increased continually, and then decreased slightly after $24 \mathrm{~h}$ (see in Fig. 3). The abundance of $p s b C$ gene transcript in treatment groups $(10,100$ and $1000 \mathrm{ng} / \mathrm{mL})$ decreased significantly $(\mathrm{P}<0.05)$ from 0 to $48 \mathrm{~h}$, but increased at $72 \mathrm{~h}$, however, such abundance was always lower $81.2 \%$ (10 ng/mL), 84.4\% (100 ng/mL), and 80.2\% (1000 ng/mL), respectively, than that of control. Once treated with TBC, the minimum abundance of $p s b C$ gene transcript appeared at $48 \mathrm{~h}$. The reduction of the expression level of $p s b C$ reached $65 \%(10 \mathrm{ng} / \mathrm{mL}), 75 \%(100 \mathrm{ng} / \mathrm{mL})$ and $85 \%(1000 \mathrm{ng} / \mathrm{mL})$ of the control, respectively. Therefore, the transcription of $p s b C$ gene was downregulated by TBC. When TBC was $1000 \mathrm{ng} / \mathrm{mL}$, such inhibition reached the maximum.

The protein encoded by $p s b C$ binds with chlorophyll $a$ in photosystem II, transporting excitation energy there. According to the experiment results, these photosynthesis genes ( $p s b C, p s a A)$ had the similar mode of expression in Nannochloropsis sp. when exposed to TBC. So the scenarios used to explain for $p s a A$ may aid to our understanding that TBC reduces the abundance of $p s b C$ gene transcript in Nannochloropsis sp. once being exposed to TBC.

\section{Conclusion}

The influence of TBC on the growth performance of Nannochloropsis $\mathrm{sp}$. and the expression of $p s a A$ and $p s b C$ were determined in this study. The growth of Nannochloropsis sp. was inhibited by TBC in a concentration dependent manner. TBC also inhibited the expression of $p s a A$ and $p s b C$. TBC had an impact on the growth and photosynthetic gene ( $p s a A, p s b C$ ) expression of Nannochloropsis sp.

\section{Conflict of interest}

None.

\section{Acknowledgments}

This work was supported by the National Natural Science Foundation China (41106148, 21307063), the Open Foundation of State Key Laboratory of Environmental Chemistry and Ecotoxicology, Chinese Academy Science (No. KF2010-14), and the The Marine Charity Project (201305022).

\section{References}

Aldenberg, T., Slob, W., 1993. Confidence limits for hazardous concentrations based on logistically distributed NOEC toxicity data. Ecotoxicology and Environmental Safety 25 (1), 48-63.

Bilgin, D.D., Zavala, J.A., Zhu, J., Clough, S.J., Ort, D.R., Delucia, E.H., 2010. Biotic stress globally downregulates photosynthesis genes. Plant, Cell \& Environment 33 (10) 1597-1613.

Bricker, T.M., 1990. The structure and function of CPa-1 and CPa-2 in photosystem II. Photosynthesis Research 24 (1), 1-13.

Cao, J., 1996. The developmental trend of plastics additives. China Chemical Industry 8 , 48-50 (in Chinese).

Chen, H., Lao, Y.M., Jiang, J.G., 2011. Effects of salinities on the gene expression of a (NAD +)-dependent glycerol-3-phosphate dehydrogenase in Dunaliella salina. Science of the Total Environment 409 (7), 1291-1297.

Cristale, J., Katsoyiannis, A., Sweetman, A.J., Jones, K.C., Lacorte, S., 2013. Occurrence and risk assessment of organophosphorus and brominated flame retardants in the River Aire (UK). Environmental Pollution 179, 194-200.

Dawson, S.P., Dennison, W.C., 1996. Effects of ultraviolet and photosynthetically active radiation on five seagrass species. Marine Biology 125 (4), 629-638.

Guillard, R.R., Ryther, J.H., 1962. Studies of marine planktonic diatoms: I. Cyclotella nana Hustedt, and Detonula confervacea (Cleve) Gran. Canadian Journal of Microbiology 8 (2), 229-239.

Hall, D.O., Rao, K.K., 1999. Photosynthesis. Cambridge University Press, Cambridge.

Han, B.P., Han, Z.G., Fu, X., 2003. Algal Photosynthesis: Mechanisms and Models. Science press, Beijing.

Johnson, P.I., Stapleton, H.M., Mukherjee, B., Hauser, R., Meeker, J.D., 2013. Associations between brominated flame retardants in house dust and hormone levels in men. Science of the Total Environment 445, 177-184.

Li, P.M., Gao, H.Y., Reto, J.S., 2005. Application of the fast chlorophyll fluorescence induction dynamics. Journal of Plant Physiology and Molecular Biology 31 (6), 559-566.

Li, J., Liang, Y., Zhang, X., Lu, J.Y., Zhang, J., Ruan, T., Zhou, Q.F., Jiang, G.B., 2011. Impaired gas bladder inflation in zebrafish exposed to a novel heterocyclic brominated flame retardant tris-(2,3-dibromopropyl) isocyanurate. Environmental Science \& Technology 45 (22), 9750-9757.

Lv, J.P., Yao, J.Y., You, Y.R., 1999. Microencapsulated TBC and its application. China Plastics Industry 27 (1), 43-44.

Qu, G.B., Shi, J.B., Li, Z.N., Ruan, T., Fu, J.J., Wang, P., Wang, T., Jiang, G.B., 2011. Detection of tris-(2,3-dibromopropyl) isocyanurate as a neuronal toxicant in environmental samples using neuronal toxicity-directed analysis. Science China: Chemistry 54 (10), 1651-1658.

Rochaix, J.D., 1996. Post-transcriptional regulation of chloroplast gene expression in Chlamydomonas reinhardtii. Plant Molecular Biology 32, 327-341.

Ruan, T., Wang, Y.W., Wang, C., Wang, P., Fu, J.J., Yin, Y.G., Qu, G.B., Wang, T., Jiang, G.B. 2009. Identification and evaluation of a novel heterocyclic brominated flame retardant tris-(2,3-dibromopropyl) isocyanurate in environmental matrices near a manufacturing plant in southern China. Environmental Science \& Technology 43 (9), 3080-3086.

Sidharthan, M., Young, K.S., Woul, L.H., Soon, P.K., Shin, H.W., 2002. TBT toxicity on the marine microalga Nannochloropsis oculata. Marine Pollution Bulletin 45 (1), 177-180.

Wang, T., Han, S.L., Ruan, T., Wang, Y.W., Feng, J.Y., Jiang, G.B., 2013. Spatial distribution and inter-year variation of hexabromocyclododecane (HBCD) and tris-(2,3-dibromopropyl) isocyanurate (TBC) in farm soils at a peri-urban region. Chemosphere 90 (2), 182-187.

Wu, X.L., Liu, R.Y., Li, H.X., Yao, Z.W., Guan, D.M., 2009. Effects of triclosan on the growth of Chlorella spp. Marine Science Bulletin 28 (3), 117-120.

Xiong, X.Y., 1999. Microencapsulated flame retardant of TBC and its implication. Flame Retardant Materials Technology 3, 1-3 (in Chinese).

Zhang, X., Li, J., Chen, M.J., Wu, L., Zhang, C., Zhang, J., Zhou, Q.F., Liang, Y., 2011. Toxicity of the brominated flame retardant tris-(2,3-dibromopropyl) isocyanurate in zebrafish (Danio rerio). Chinese Science Bulletin 56 (15), 1548-1555. 